\title{
On Confucian Thought of Ya Music Teaching in Pre-Qin Period Yong-Qiang LEI
}

\author{
School of Maxism, Henan University of Science \& Technology, China \\ lyq@haust.edu.cn
}

Keywords: Confucian thought; Music teaching; Cultivation of virtue; Perfect personality.

\begin{abstract}
The Confucian thought of Ya music education originated from the sacrificial ceremonies in the primitive society. In the sacrificial ceremonies, people tried to please gods with music and dance, with a strong utilitarian purpose. With the "philosophical breakthrough" in the Spring and Autumn Period, Confucius was the forerunner of private schools and founded the Confucian school of thought. In the process of removing the witch, Confucius emphasized the educational function of Ya music on the people, taking Ya music as an effective tool to train political talents, to improve the personal moral personality and to enhance the aesthetic realm, etc. The effort made by Confucius was inherited by the generations of later Confucians, which formed the tradition of the Confucian Ya music education.
\end{abstract}

\section{Introduction}

As an educational form, music teaching originates from ceremonies or rites for serving gods. In primitive society, the music officer educated the eldest son of emperor or aristocrats by music in the clan, and held sacrificial ceremonies of dance accompanied by music for gods descending and serving gods repeatedly. With the formation of class society and appearance of country, the class of slave owners set up the special school for cultivating children of the nobility. However, the music teaching of Xia and Shang Dynasties were held still in the air of serving gods without consciousness or awareness of educating by music in such respect as politics, morality and aesthetics, etc. Lv Simian once said that when the world was in deep superstition, the people will be pious in serving gods, which leads to the setting up of the rites and music education. Then the superstitions grew faint, and the rites and music education changed and became the tools to cultivate people physically and mentally. [1] Music teaching of the Western Zhou Dynasty contained more remarkable consciousnesses than that of Xia and Shang Dynasties, which was reflected in institutionalization of music teaching.Duke Zhou provided conditions for development of Ya music teaching in Zhou Dynasty with his creations of rites and music. The rich tradition of Ya music teaching in Zhou Dynasty, a cradle of Confucian theories of Ya music teaching, makes a direct, profound and lasting influence on the following Confucians.

Confucius was the founder of Confucian school in pre-Qin Period. He is not only a great thinker, but also an outstanding educator of music. With a strong awareness of potential problems and a sense of historical responsibility, he undertook the work of inheritance and continuation of Confucian orthodoxy consciously, and did lots of work in correcting errors aiming at the tendency of formalization and the tendency with attention to small details of emperors in ancient times. With a deep understanding of the cultural break caused by the falling of the traditional rites and music education, he did his best to rebuild the link between traditional cultural classics and the real life world, and regarded music as the life form concerning human spirits and emotions, releasing from the set pattern of previous music teaching with a view of pleasing gods. So human rational consciousness was awakened and moral personhood stood erectly. The humane transformation of the music began after it was freed from religious authority, which passed down by subsequent Confucians (Mencius, Hsun-tzu, etc) continuously, and the tradition of the Confucian music teaching was formed historically.

The term "music teaching" makes its first appearance in the classic of Confucian-An introduction on five classics of the Book of Rite(chapter Jing Jie of $\mathrm{Li} \mathrm{Ji}$ ), which defines music teaching by virtue of Confucius, that is, "the music teaching aims at shaping a person with a broad 
affable kind heart, namely, one with a broad affable kind heart is deep in music consequentially". The sentence above is not necessarily from Confucius, however, as a comprehensive commentary associating with Six Disciplines, it covers many aspects of music teaching of Confucian, motive theory, epistemology, methods of music teaching, the training goal of moral personhood, and so on. The author will expound the function of music teaching from three aspects: political dimension, moral dimension and aesthetic dimension.

\section{The Ya Music Education is an Effective Tool to Train Political Talents}

In ancient society, it was generally believed that the music was a barometer of politics. Because the music or the folk songs singing was the real reflections of sufferings of the people's livelihood, so the ruler paid much attention to making out political situation by examining the music. In order to know the situation of the lower classes, the imperial court of the ancient society often sent some blind musicians into the folk to collect the folk songs. When the folk songs were played in an authentic way in the court, the ruler would know the popular support or the lack of it from the lower classes and make a political change accordingly. Until the Song Dynasty, Zhu Xi, the great Confucian scholar, still insisted that the songs from the underclass can check the ups and downs of customs, and see the political gains and losses.[2] Meanwhile, in order to make the rulers understand their needs, the people of the lower social class often admonished by offering music. The two-way demand promoted the perfection of the system in collecting and presenting songs.

When it came to the Spring and Autumn Period, especially in the political and diplomatic occasions, the scholar-bureaucrats proclaiming one's ideas by poems singing, which became an effective means of political communication between vassal states. So, just as Confucius said that if a man did not learn music, he would have nothing to say(chapter Ji Shi in the Analects of Confucius). In other words, to master the skills of music and be familiar with the response by songs is the basic quality of a qualified political talent. So, By music teaching, one batch after another of great men with outstanding political understanding emerge.

Moreover, music has the function of uniting the whole clan group. When people sing a poem together, it can arouse people's sense of identity to the whole group. The practical purpose in setting up the system of rites and music in Zhou Dynasty is to preserve the existing order, which is the dialectics in Confucian ideas of the rites and music.[3]From the standpoint of Confucian, the ceremony or rite signifies discrimination, and music means blending, namely, as two approaches to realize the harmony of society, the rite and music are interdependent. Due to it, great men and the common people do their proper shares, and the relationship of social ranks could be brought into properly in favor of formation of the harmony of the whole society. Therefore, music teaching is deeply connected with politics in ancient society.

\section{The Ya Music Education is an Effective Tool to Improve the Personal Moral Personality}

Cao Fulin said that in the study of ancient Chinese thought, "De" is a complex concept. Commentators tend to interpret it directly as "morality", which is not appropriate in understanding the "De" concept of pre-Qin period.[4] Mr. Cao is right. Because the word "De" didn't mean "morality" at the start of its appearance. It had experienced the development for quite a long time, and finally penetrated into people's inner psychological level, and became similar with the word "goodness" in moral judgment. With the setting up of the system of the rites and music by Duke Zhou, the trend to cultivate inner virtue by music in Zhou Dynasty would become inevitable in history.

Focusing on the cultivation of virtue by Ya music education began with Zhou Dynasty. The idea that the morality is the gains runs through the whole course of the development of human moral reason. It not only reflects the utilitarian needs of human beings, the expression of the real personal emotions, but also the opening of the institutional rationality and the transcendent realization of the human's inner virtue. From the virtue of heaven to personal virtue of spirit and morality is the process of the discovery of the human self, and people's subjectivity is highlighted. The human is 
dominated by the moral heart, in which the knowledge and the emotion are in harmony. So the morality is not only inherent in it, but also tend to open to the outside world inevitably.

With the function of exhortation, the Ya music could purify one's mind in cultivating of virtues, which is reflected in one's daily life. Confucians in pre-Qin period holds that one can understand the inner meaning of the music really only if his moral personhood is perfect. By the light of moral reason, differences on value orientation between the great man and the man without virtue emerge evidently, namely, the great man takes attainment of Tao as pleasure, whereas, the man without virtue takes satisfaction of appetite as pleasure.

Moreover, music is the exterior manifestation of inner virtue, so the gentleman can embody his inner virtue. Educate people and change existing habits and customs by creating music patiently and gently, so that everyone doesn't concern about selfish desires and remains in his proper place to get free with moral personhood.

\section{The Ya Music Education is An Effective Tool to Enhance the Aesthetic Realm}

Music teaching of Confucian also contains aesthetic dimension, which arises from aesthetic pleasure of people, and also finishes up with it. The former, chiefly the spiritual aesthetic joy obtained by enjoying the court music, is moral sphere of living. And the latter, chiefly the immense perfect happiness gained by understanding the Tao, is heavenly sphere of living. "Equilibrium and harmony" is not only doctrine of the court music but also that of "great enjoyment". The latter is the metaphysical basis of the former, and the former is the embodiment of the latter. The harmony of cosmos, a great beauty formed in the unity of many distinctions, lies in resolving the contradictions between human and nature. Confucian advocating of music teaching is to pursue a harmonious and happy sphere of cosmos and living which is a perfect combination of care and joy.

In the process of music teaching, Confucians paid attention to the edifying effects of the character by music education, and advocated the use of Ya music in order to achieve the purpose of aesthetic education. In the music aesthetics, the music is not just for music in the eyes of Confucians, but the aesthetic human life, namely, the Confucian music-centered personality that the art is for life.[5]Confucius said that completing in the music just means the same way and aims to the achievements of the moral personality. People can rise to the moral realm, and can make the virtue fully revealed, which is commendable. But Confucius believes that the gentleman should also have higher pursuit, it is "the ascending of the man of noble character ". Ascending means rising up in the spirit, and eventually achieves the harmony between man and Heaven. Zeng Dian's Enjoyment was the transcendental aesthetic realm in Confucius' eyes.

Mencius took the sincerity reflection as the way up to the heaven. He said that the sincerity was the Way of Heaven, and the sincerity reflection was the Way of man. Mencius distinguished the Way of Heaven from the Way of man, which was actually to explain the sincerity from the point of view that man and nature are in a harmonious unity. The sincerity is the noumenon of the heaven, and benevolence is the implementation of the Way of heaven in man's heart. So sincerity reflection is the recognition inward, which also the Kung Fu to reach the noumenon of the sincerity. Mencius claimed to educate people by benevolent music, which was to urge people to recognize the intrinsic benevolence in the benevolent music, with the purpose to obtain a kind of spiritual enjoyment. Mencius also said that man's reasonable desire was called goodness, keeping it in oneself was the sincerity, being full of it was the beauty, being full and bright was great, being great and changing was saint, being saint and unknowable was God. (Jinxin Chapter of Mencius) Therefore, people perceives intuitively in the moral evaluation and aesthetic evaluation of the goodness, sincerity, beauty, and greatness, and experiences the utmost enjoyment in the realm changing with the world. The Mencius' realm of utmost enjoyment was the state that enjoyment and the sincerity are in unity, the truth, goodness and beauty are in unity as well.

Xunzi also paid attention to the subject's enjoyment of the aesthetic experience. He put forward the proposition that if one was not pure and comprehensive enough unworthy of beauty. This pure and comprehensive personality is a Sage, who are the unity of internal and external consistency. So, Xunzi stick to learning, and the ultimate goal was to be the Sage by learning. The sage can reach the 
sage realm, which is a higher realm of heaven and man, beyond the moral realm. Thus, the realm of beauty and the realm of benevolence forms an unity. In the realm, the internal world and the external world are open. That is, the universe and human beings have the same structure, same principles, infiltrate into each other and merge into an organic whole. It is a Clear state, in which the beauty and goodness forms an unity as well. And it is the ultimate aesthetic ideal that Xunzi stressed by music teaching.

\section{Conclusion}

As the founder of Confucian theories of music teaching, Confucius who lived in the disordered Spring and Autumn Period when rites and the music fell, put forward his theories of music teaching, aiming at the turbulent phenomenon. Owing to the deep regretting of the break of court music, Confucius returned to Lu from Wei and amended music in his later years, excluding the music of Zheng and advocating the court music. He guided the differentiation from the court music and the secular music of Confucian music teaching in Pre-Qin Period, and brought about continuation of the court music, opening the door of the development of Chinese traditional Ya-music teaching.

According to the research above, we should reflect upon the fracture of the tradition in music teaching by researching on Confucian ideas of music teaching in pre-Qin period, and keep a health metal attitude in developing national music. That is, we should self-respect and self-confident about Chinese ancient music heritage and excellent music tradition, and create new elements on music culture on the basis of inheritance of outstanding heritage, in order to bring about modern transformation of Confucian traditional ideas of music teaching; meanwhile, absorption and acceptance of advanced graceful parts of foreign music which are suitable to us are also very important. We should direct our ways to the combination of Chinese and western culture, constructing and developing the global system of musical teaching energetically. Furthermore, reconstruction of national system of music by means of excavating traditional Confucian thoughts of music teaching turns out to be an important way to cope with the global culture challenge and to get out a tight spot of the tradition.

\section{Acknowledgement}

This research was financially supported by National Social Science Fund Project (12CZX 032), Henan Province Education Department Innovative Talents Project.

\section{References}

[1]Lv Simian. Lv Simian's Notes in Reading History. Shanghai :Shanghai Ancient Books Publishing House,1982,P453.

[2]Zhu Xi. Si Shu Ji Zhu(the Commentaries of the Four Classics), Xi 'an: San Qin Publishing House, 1998, page 217.

[3]Pang Pu. The Study of Confucian Dialectics. Beijing: Zhonghua Book Company(Zhonghua press), 1984,page46.

[4]Cao Fulin. The Origin and Development of the Concept "De"in pre-Qin Period, published in "Chinese Social Science", 2005, Vol4.

[5]Xu Fuguan. The Chinese Artistic Spirit, Guilin: Guangxi Normal University Press, 2007, page 19. 